\title{
G

\section{Transitive Business Model of Management in Central Europe - Torn between East and West}

\author{
Artur K. Modliński
}

\begin{abstract}
A B S T R A C T
Objective: The objective of the article is to present the internal and external model of management and how it is connected to the political system and national culture among the Visegrad countries. The paper presents several examples of transitive models of management. It aims to indicate which advantages and disadvantages can be identified in the transitive groups, how they can influences the international investment potential and image of the company.
\end{abstract}

Research Design \& Methods: Qualitative research on a sample of Polish, German and Ukrainian companies combined with secondary data.

Findings: Polish business culture can be regarded as transitive - the influence of two bordering civilization (Western and Orthodox) is noticeable. This phenomenon has shaped the business values and it is still present in the international context.

Implications \& Recommendations: The transitive business model of management allows to predict and avoid the problems occurring in the internal and external relationships in the companies from Central Europe who are involved into international projects.

Contribution \& Value Added: The paper enables the clarification of the transitive management culture; the juxtaposition of differences and similarities and their impacts of the internal and external business relationships; the explicitness of dichotomy and its influence on international business image of Visegrad countries.

\begin{tabular}{ll}
\hline Article type: & research paper \\
Keywords: & international management; corporate culture; management models \\
JEL codes: & $\mathrm{M} 00, \mathrm{M} 14, \mathrm{M} 16$
\end{tabular}

Published by Centre for Strategic and International Entrepreneurship - Krakow, Poland

\section{Suggested citation:}

Modlinski, A.K., (2013). Transitive Business Model of Management in Eastern Europe - Torn between East and West. Entrepreneurial Business and Economics Review, 1(2), pp. 59-72. 


\section{INTRODUCTION}

The phenomenon of the management culture is described in the literature as a set of values and attitudes which are specific for a particular organization (Cameron \& Quinn, 2011). In various articles and scientific applications management culture and organizational culture are used interchangeably. From the epistemological point of view, it should be approved to follow this tendency also in this paper. One of the categorizations which is used to split management culture into subcategories is national culture. Such factors as tradition, historic experience, religion can influence the way in which people of a particular organization are functioning and performing their jobs. However, the list of factors which can be considered as components of the management culture is wider and unspecified. The political dimension takes into account the political system as one of this factor and examines how it can affect the organization.

The socio-political background of Visegrad countries is strongly associated with their abandonment of socialism and transition to a democratic system. In communism the private companies were not able to function and this state of affairs have an impact on social mentality. In cases where the system is transformed from communism to democracy, the level of preparedness to work in the private sector or setting up their own business is less than in consolidated democracies. Since 1945 both Poland, the Czech Republic, Slovakia and Hungary were under soviet influence. West civilization was in the opposition to economic views of communism. In the Visegrad countries the establishing private companies were either undesirable or prohibited. Over the approximately forty five years, a model of social coexistence characteristic for the countries of the former Soviet Union influence people lifestyles in the countries of current Visegrad group.

The objective of the research on management culture and business model of Visegrad countries was to examine if a transitive model is a real phenomenon which is occurring after the transformation of the political system and is noticeable for next decades in the internal behaviours of working groups. The research purpose was to analyse the attitudes of a chosen country and to compare it with neighbouring ones to detect the similarities and differences in management cultures. The third objective was to assess which barrier can provoke the dualism in management culture and which impact it has on image and international cooperation.

\section{LITERATURE REVIEW}

Attempts to determine what management culture is and how it affects the management process were undertaken by numerous researchers. Edgar Schein has defined organizational culture as "the totality of fundamental assumptions that a given group has invented, discovered or developed to adapt to environmental and internal integration" (Schein, 2010). The point of interest was how national cultures (with all specific rituals, traditions, experiences and values) can influence the type of management and organization in particular countries. The naturalistic approach presented by Gareth Morgan suggests that each organization has its unique culture and coexistence of people (with their values, attitudes and behaviours) can be an example of "micro society", directed into survival and promotion in the hierarchy of the group (Morgan, 1997). To 
compare the organizational cultures from various countries models and measurements are crucial. Geert Hofstede, Gert Jan Hofstede and Michael Minkov by examining the fields in which cultural similarities and differences were observable, they pointed out the following cultural dimensions (Hofstede, Hofstede \& Minkov, 2011):

- collectivism vs. individualism,

- power distance index,

- masculinity vs. femininity,

- uncertainty avoidance index,

- restraint vs. indulgence,

- long term orientation vs. short term orientation.

Based on these dimensions, the group of researchers lead by Geert Hofstede has started to examine people in particular countries to compare in which fields they are differing. Because of such comparison it was possible to point out where conflicts of interest or misunderstandings, leading to the decrease in organizational performance, can potentially occur.

A different competitive categorization was constructed by Charles Hampden-Turner and Alfons Trompenaars (1998). This group has also focused on national culture differences and their impact on conditions of the organization. They proposed the following categorization (Hampden-Turner \& Trompenaars, 1998):

- neutral versus emotional culture,

- sequential versus synchronic culture,

- individualism versus collectivism,

- universalism versus particularism,

- specific versus diffuse,

- external versus internal control,

- ascription versus achievements.

From the anthropological and psychological point of view such set of determinants is more relevant to examine how the inside process of management is running. In the categorization of Hampden-Turner's and Trompenaars' model, especially type of control and gaining position in the hierarchy are crucial and novel. Because of these elements it is possible to observe how groups can react when interaction with different type of culture occurs. Trompenaars and Hampden-Turner have focused on only seven different countries and regarding the type of the organizational cultures: USA, Germany, France, Sweden, the Netherlands, Great Britain and Japan. The choice of such examples was mainly due to the fact that in the time when research was conducted, these countries have played a dominant role in the global economy. Also the contrast method was playing a vital role because the differences in organizational cultures of proposed national cultures are the most visible. In both categorizations the researchers has chosen the countries and nationalities as reference objects for examining the organizational cultures. It can be called the micro approach. The macro approach however, is focusing on the similarities and differences between whole civilizations.

Focusing on business culture two researchers are essential to be quoted - John Mole (2003 quoted in Wach, 2013, p. 153) and Richard R. Gesteland (2005 quoted in Wach, 2013, p. 154). Mole introduced a map of entrepreneurship culture taking two dimensions - leadership model and organization model. Gesteland introduced four pairs 
of business culture dimensions (relationship-focused vs. deal-focused, formal vs. nonformal, time-fluid vs. rigid-time, expressive vs. reserved business behaviours).

In the theory of Samuel Huntington (2011), the American political scientist implied that nine civilizations are playing an important role in the world: Western, Orthodox, Islamic, Latin American, Japanese, Buddhist, Hindu, Sinic and African (Huntington, 2011). Such categorization was made because of religion, historic experience and tradition. According to Huntington all of these civilizations were different because of values, attitudes and behaviours shared by their societies and for this reason their confrontation was seen as a danger for peaceful coexistence. How such clashes of cultures, therefore, can influence the global management and economy? This subject, however, was not in the strict centre of Huntington's scientific interest but his successors started to examine the interrelation of civilization clash and global economy (Conrad \& Pool, 2012).

First researches on cultural clusters were done in 1960's by M. Haire, E.E. Ghiselli and L.W. Porter (1966). Since then the term "cultural clusters" have started to be universally used, being also the object of further academic research. In the context of organizational studies and management, cultural clusters can be defined as groups of countries with similar cultural values (Haire, Ghiselli \& Porter, 1966). The most commonly used is the concept of division by S. Ronen and O. Shenkar (1985) who have pointed out such clusters as: Nordic, Germanic, Anglo-Saxon, Latin European, Latin American, Arabic, Far East and independent national clusters (Brazil, Japan, India, Israel) (Bachnik, 2010). Taking Europe into special consideration John Mole (2003, p. 55 quoted in Wach, 2013, p. 152) points out five different culture clusters, namely Atlantic culture, North Sea culture, Mediterranean Sea culture (including a special subgroup of the Danube region culture), Baltic culture and Black Sea Culture. Krzysztof Wach (2013, p. 151-152) suggests six culture clusters in Europe, namely:

- Anglo-Saxon culture (UK, Ireland),

- Nordic culture (Denmark, Finland, Iceland, Sweden, Norway, Estonia),

- Northern European (Germanic) culture (Austria, Germany, the Netherlands, Switzerland, Belgium, Luxembourg),

- Southern European (Mediterranean) culture (France, Greece, Spain, Portugal, Italy, Slovenia, Croatia),

- Central European Culture (Poland, the Czech Republic, Slovakia, Hungary),

- Eastern European culture (Lithuania, Latvia, Ukraine, Belarus, Russia).

Any of the presented research has not taken into account, however, how political systems and their transformation can influence the organizational culture in a country affected by the system change. Culture is a phenomenon which can develop freely in a democracy. In totalitarianism or autocracy the government can lead to remodelling of traditional values if they are not coinciding with official political doctrine (Magstad, 2012). The question whether political system has an impact on organizational behaviour is followed by whether a mark it left on attitudes and behaviours of people in the area of cooperation or organizational coexistence when system transforms from totalitarianism or autocracy into democracy.

The collapse of Soviet bloc has redefined the European policy and it had various consequences for countries which were previously under its influence. These countries chose to integrate with western culture both in a military and economic way. However, 
to be perceived as trustworthy partners, they were obliged to retransform their existing systems almost in every field. Management was one of such fields (Balcerowicz, 1996).

\section{MATERIAL AND METHODS}

\section{Goals of the Research}

The Visegrad countries were previously under influence of soviet ideology and then started the democratic, pro-western transformation, based on the patterns from western countries. How did mentality, internal behavior and management culture change because along this road?

The superior purpose of the research on management culture of countries from Visegrad group was to verify the differences and similarities in the field of organizational culture in comparison to western countries and orthodox countries to detect the transitive model of management defined as mix of organizational values and attitudes. The objective was to identify in which area of internal and external coexistence the Visegrad countries are similar to Eastern or Western civilization. The goal was also to determine what results these differences and similarities can have on cooperation with business partner from Western and Orthodox civilizations.

Finally the research was designed to determine whether after more than two decades after the political transformation, the organizational culture of a chosen country was more similar to those from Western or Orthodox civilization.

\section{Hypothesis}

Upon observations made on a random sample of people engaged into cooperation with international partners, it is hypothesized that workers from Visegrad countries have different, unique sets of values and mentality which are a mix of Western or Orthodox cultures. Moreover, it was pointed out that this set of values and mentality is transforming into the Western model. This would be one of the element which should have supported the theory about transitive model of management culture. The general idea was that countries which changed their political system even twenty years ago and integrated with Western civilization still share some sets of values with countries which belong to Orthodox civilization.

\section{Research Methods}

The research was divided into two parts. First one was observation and collecting the secondary data about organizational cultures of Poland, Hungary, the Czech Republic and Slovakia. In was taking into account the assumption that bordering countries can influence the particular culture. Looking for the most appropriate example from Visegrad countries which could be applied to comparison with neighbors in geographical and demographical way.

As direct neighbour from Western culture, Germany was selected as first reference group. To meet the demographical requirements and scope, Ukraine was selected as reference sample from Orthodox civilization. Because it was presumed that the phenomenon of transitive management model was typical for all Visegrad countries, Poland was selected as random group with clear stipulation that other Visegrad countries should be examined as references in the future. In such research both 
qualitative and quantitative methods would be appropriate from the methodological point of view. However, to illustrate the results in most precise way, the quantitative method was finally chosen.

In the second stage the population from Germany, Poland and Ukraine were compared, basing on the vestigial questionnaire used in the project GLOBE (realized by Geert Hofstede). To conduct the comparative analysis the worksheet was the same for all groups. The research sample included 100 responders. The sample consisted of three groups of responders - 25 from Germany (25\%), 48 from Poland (48\%) and 27 from Ukraine (27\%). The responders were business workers involved in the any international cooperation with foreign partners or any international projects. The sample age group was 19-40. The data was collected in Germany, Poland and Ukraine over a period of three months (from September to November 2012).

\section{Fields of Interest and Replication}

The questionnaire included 36 closed and 4 open questions. Each respondent received the printed questionnaire. Questions were constructed to examine and compare five fields perceived as crucial from the point of view of management culture. These were:

- level of nationalism (to examine how people react to coworkers from other countries),

- individualism/ collectivism (to check if the object of the worker is personal

- or common success),

- role of leader in the group (to verify how groups perceive the leader opinion),

- role of religion (to compare if religion is playing come role in management and organization as well as if Polish culture is more religion independent as Germany or dependent as Ukraine),

- hierarchy or equality (to check the formality of coexistence).

Such fields considered as important by all theoreticians presented in the material, should be regarded as model of verification the similarities and differences. To allow the replication of the research in the future, the question and statements used in the questionnaire are presenting in the fourth section as title of particular diagrams.

\section{RESULTS AND DISCUSSION}

\section{National-centricity}

National-centricity defined as conviction that a particular nation with its tangible and intangible effects of existence is better than other is perceived as a problematic phenomenon in the international cooperation as far as it limits the potential of the team. There were two questions about direct and indirect forms of national-centricity in the questionnaire.

The lowest tendency of identification with native country was in the German sample. Only $33 \%$ of the group have chosen affirmative answer. It can be explained by historic experience and education in modern school which focus on the consequences of German totalitarianism. The highest level of full identification with native country was observed in the Polish sample - $44 \%$ affirmed the complete identification and $44 \%-$ partly identification. Also in this example the historic perspective can explain the phenomenon - Poland for years has relied on the traditionalism and patriotism to 
preserve its culture in the time of foreign influences. Ukrainians demonstrate the highest level of total identification with their nation which can be defined as $100 \%$ of affirmative answers (in comparison Germany - 33, Poland - 88, Ukraine - 100). Among the Ukrainian sample $71 \%$ rather identify with their country and $29 \%$ - completely. Basing on the index of total identification it can be stated that Poland is between Germany and Ukraine in the identification of people with their country. However, on the comparative scale, Poland is more similar to Ukraine than to Germany in this field.

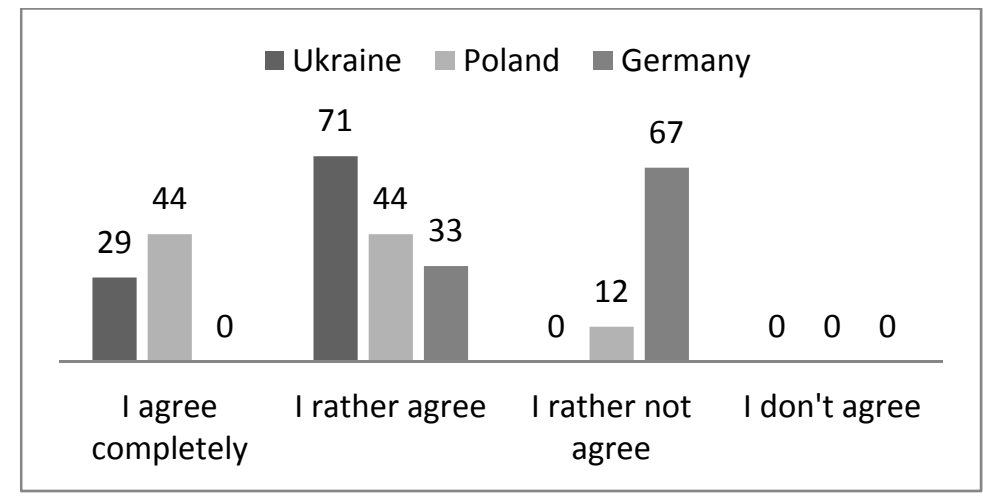

Figure 1. Identification with national culture (in \%)

Source: Author's elaboration based on own survey $(\mathrm{N}=100)$.

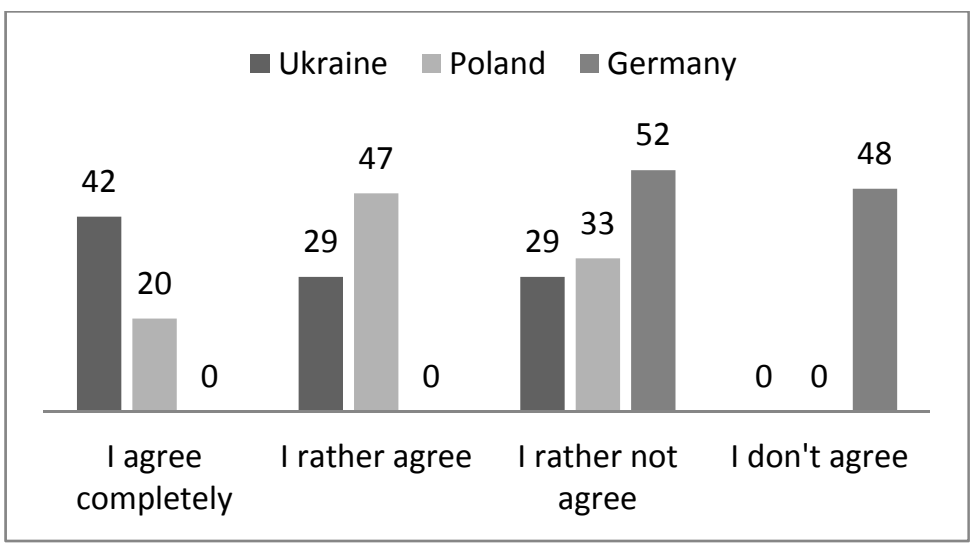

Figure 2. Superiority of own national interest over others (in \%) Source: Author's elaboration based on own survey $(\mathrm{N}=100)$.

The direct question about national-centricity was asked in the form of country interests. $71 \%$ of Ukrainians, $67 \%$ of Polish sample and $0 \%$ of Germans claimed that the interests of their countries are more important than interests of others. $100 \%$ of Germans believed that this assumption is false. Also in this question, the historic experience is most likely observable. National-centricity is perceived as negative phenomenon after political repression of Nazi regime. Level of intensity of nationalcentricity is similar for Poland and Ukraine. 
From the point of view of organizational or management studies the cooperation with national-centered workers in international projects is harder than with neutrals. The process of team building, responsibilities shares and consolidation of power is subdued by prejudices. Both neutral and national-centered workers can have problems with successful cooperation in such environments. In this field Poland is in the middle of scale between Germany and Ukraine with still existing tendency of national-centricity.

\section{Individualism vs. Collectivism}

Investigating the level of collectivism or individualism in the chosen groups, the higher intensity of collectivism was noticed among German respondents. Only $26 \%$ of them believed that personal success is more important than success of the group. These results question the stereotype that Orthodox culture is more collectivist than Western one.

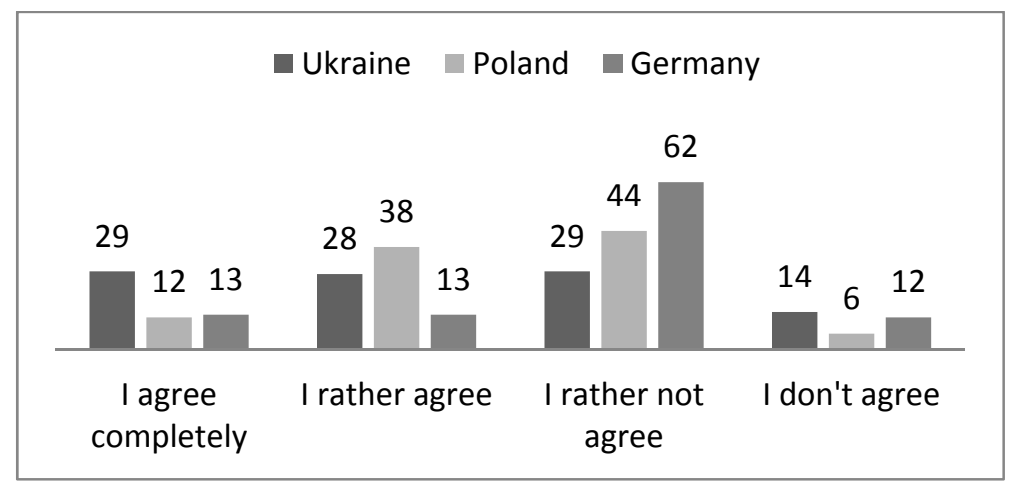

Figure 3. Individualism superiority over collectivism (in \%)

Source: Author's elaboration based on own survey $(\mathrm{N}=100)$.

Polish group was more differentiating; as much as half of them has presented individualistic attitudes. Such dispersion of results suggests that the group is not compact and implies the existence of a transitive model in management. One of the reasons for this can be different sources of cultural examples which have an impact on workers mentality. Polish representatives are more similar in their perspective to the Ukrainians than to Germans. In this field the building of international group of representatives with such attitudes would demand the focus on "mission and objectives". Upon these results cooperation between Polish and Ukrainians would be characterized by higher understanding of internal behaviors.

\section{Role of Leader in the Group}

Position of the leader is integral part of group hierarchy and it can influence the internal and external cooperation. There are cultures in which leader's opinion is ultimate and unquestionable and cultures where coworkers are serving as leaders in their own fields of expertise. Orthodox culture is described in the literature as authoritative so the leader's opinion would be perceived as important for this group. 


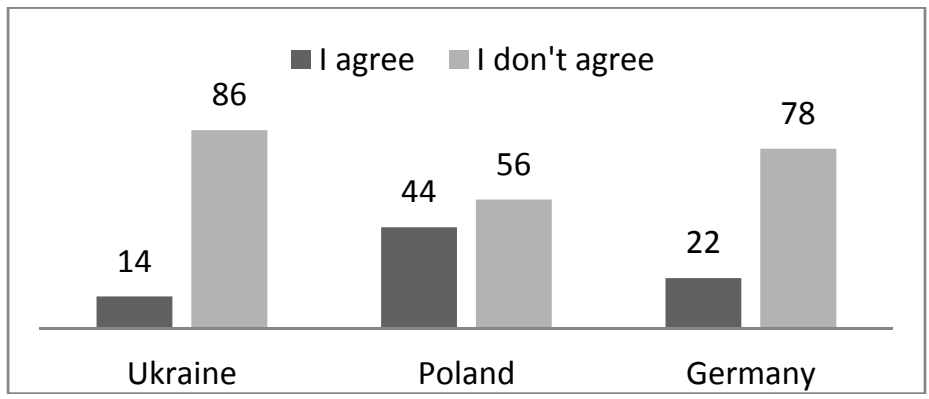

Figure 4. The role of leader in the group decision making as dominant factor (in \%) Source: Author's elaboration based on own survey $(\mathrm{N}=100)$.

The results show that Ukrainians and Germans are not leader-centered. The presumptions from earlier studies suggest that Ukrainians are leader-centered. It was, however, not confirmed in this research. Polish sample was also differentiated. 44\% supported the idea that leader opinion is crucial for the group and $56 \%$ were against this idea. Hence, Polish respondents had highest factor of leader-centricity, at least from the declarative point of view. Also in this field the mix in opinion is visible what strengthen the opinion that Polish management culture is a transitive one. To further explore these attitudes and behaviors, qualitative research should be pursued in the future.

\section{Religion and Workplace}

In Orthodox civilization religion is perceived as important factor which influences the national identity. After the collapse of Soviet bloc, religion impact on local society has strengthened. The ideology which is bound with religion can have an impact on attitudes and behaviors in the work place. Undoubtedly it is one of the factor which influence the organizational culture, management process and internal relations between group members.

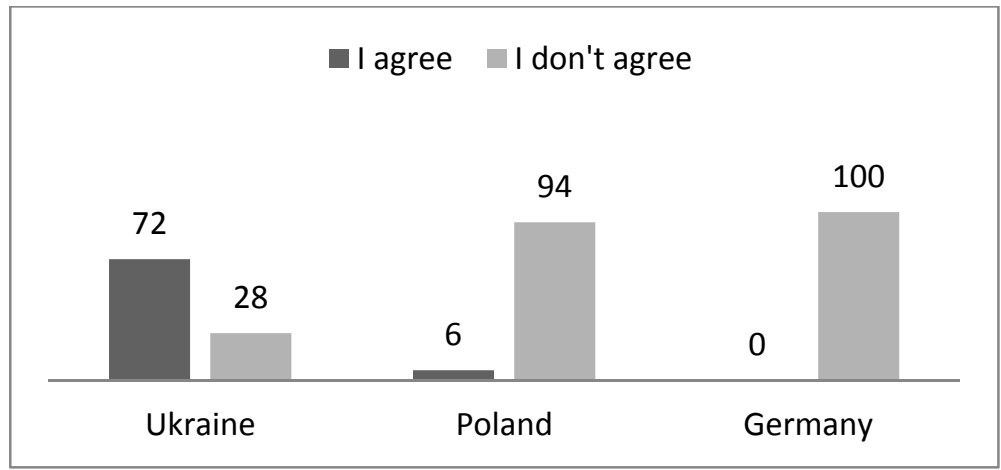

Figure 5. Acceptance for religion in the workplace (in \%)

Source: Author's elaboration based on own survey $(\mathrm{N}=100)$. 
For $72 \%$ of Ukrainians religion plays an important role. Hence, the religious attitudes bind group members. Understanding of dichotomy in thinking about crucial problems can be problematic.

All members of German sample consider religion as not important factor in workplace and similar model is presented by Polish workers The older workers should indicate other tendencies in this field. In case of cooperation and team building between representatives of these three cultures, religious motivations in workplace can lead to misunderstandings. The leader of the group should focus that such differences in organizational cultures must lead to appropriate projection of management process.

\section{Hierarchy vs. Equality}

The last attribute considered as part of organization culture included in the research was attitudes towards hierarchy and equity in the group. It is closely related to the results presented in Figure 4 (The role of leader in the group decision making as dominant factor). Hierarchy, however, is not only position of leader in the group but it describes all relations in the team (between coworkers, departments and different position in the company).

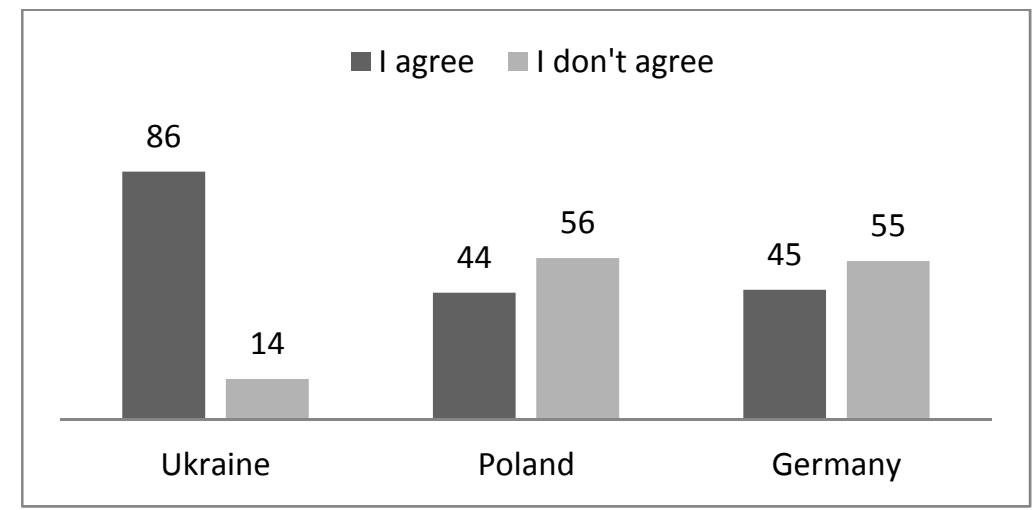

Figure 6. Hierarchy and equity in the workplace (in \%)

Source: Author's elaboration based on own survey $(\mathrm{N}=100)$.

The results show clearly that hierarchy is perceived as natural phenomenon by Ukrainians. $86 \%$ of them affirmed that the presence of formal interdependencies is a crucial factor for effective work. Such results are corresponding to the earlier question concerning the position of the leader where majority of Ukrainians claimed that his/her opinion is the most obliging. The conclusion is that the organizational culture and management process in the Ukrainian group is leader-centered.

German and Polish respondents were similar in the field of hierarchy importance. About $55 \%$ of both groups claimed that hierarchic structure is not necessary for effective cooperation.

\section{Transitive Model of Management}

Transitive model in organizational culture can be perceived as a phenomenon which occurs when a country or company is under influence of another type of culture and the 
native culture of particular company or country is acquiring the rules and norms typical for different subjects. This is, however, not a static but dynamic process. The change in organizational culture and management is not rapid. The core of the phenomenon is existence of two sources of value. In the article Western and Orthodox cultures were used as such references.

In the initial stage of research the hypothesis was presumed that Poland as one of the example of Visegrad group countries is an example of such transitive model. After the research the similarities and differences between German, Polish and Ukrainians organizational cultures were detected. Poland was more similar to Ukraine in such fields as national-centricity and individualism. With Germany such features as hierarchy factors, attitudes about religion and leader position are shared. Poland is an example of transitive model because it is not centered into only one dimension of influence. It cannot be, however, stated that in this moment this model is present in Polish organizational culture and management because transitive model is, as it was stated above, a dynamic process. Therefore, the research should be replicated in the future to confront if Polish values and attitudes shift in time and which source of impact has affected the culture.

The research conclusions help to determine that transitive management model can occur not only when values and mentalities of an organization are torn between two sources of cultural impact but also when the reference group is internally divided in their opinions and values. Such tendency can be observed especially long periods after a political system transformation. Some workers adapt to new challenges while others remain rooted in the past. Transitive model management was never regarded as scientific wrongly. Not only external dispersion but also internal division should be primary evidence of transition. However, without periodical replication of the research, unequivocal detection of transitive management model is not scientifically possible.

\section{CONCLUSIONS}

The conducted research exposed Poland as an example of Visegrad group country which upon the analysed data was perceived as most transitive. Organizational cultures in the Czech Republic and Hungary were more similar to German. Slovakia and Poland were characterized by many indexes similar to both Western and Orthodox countries. Ultimately Poland was chosen as an example for the research because of demographic and geographical factors which were most analogical to Ukrainian and German sample.

As it was assumed that transitive model management must meet two conditions: mix of organizational models, management cultures of at least two different cultural sources (civilizations, countries) and internal diversity among particular group, it shall be stated that Polish management model is transitive.

A crucial factor for confirmation the transitive management model occurrence is to repeat the research after five years since transitiveness is a dynamic process and static research presented in this paper is only the initial stage of research. The study indicates that Polish organizational culture exhibits patterns of both Western and Orthodox influence. It is highly recommended to continue the studies in the future to establish how values and attitudes will transform and in which direction they will shift. 
From the critical point of view the concept of transitive model is disputed. The mix and merge of cultural value is a common phenomenon but there is also an assumption that each country and society shares different values, attitudes and experiences and therefore even a small group is able to generate their own, unique set of values which can influence the local organizational cultures. On the other hand, each organization can demonstrate distinctive set of principles and codex. National or ethnic values can be perceived as factors which influence the organizational culture and management process, but does it mean that they are playing a dominant role in the final shape of organizational culture? Hence, the reflections on transitive model of organizational cultures and management can be broadly discussed.

Along with the academic discussions, it should be noticed that cultural values are interchanging in the era of globalization and have essential role in the management models and organizational internal and external behaviours. It should be taken into account that these factors are influenced by political systems, freedom of speech, national culture, religion and ideology. It cannot be ignore that external cultural sources have an impact on our organization and therefore the workers mentality.

Presented in the material differences and similarities are important from the point of view of international cooperation. Differences in management models and organizational cultures can lead to misunderstandings and impact the performance of the team. Similarities can be helpful in such performance and team building process, because the principles of coexistence are transparent. What is even more worth mentioning is, however, the fact that differences can also complete each other and they can strengthen the international team. Transitive management model is not necessarily an obstacle from the point of view of international cooperation.

Undoubtedly, a crucial limitation of research is the magnitude of proposed indexes and distinguished features served to describe the cultures of nations, countries and organizations. In this article the major point of reference were indexes proposed by Geert Hoftede, Mauk Mulder and Gerry Johnson since they seem to have the highest probability of verification. Yet many other propositions are available and used.

As it was pointed out, from the scientific point of view the concept of transitive model in organizational culture or management is unverifiable in short periods of time and for this reason, the presented findings can only serve as initial stage in phenomenon detection. As Visegrad countries are culturally unique, each of them should be researched separately to provide insight into the regional specifics of transitive model management.

\section{REFERENCES}

Bachnik, K., 2010, Skandynawskie uwarunkowania kulturowe w procesach zarzqdzania. Wydawnictwo Fachowe CeDeWu.pl, Warszawa.

Balcerowicz, L., 1996, Socialism, Capitalism, Transformation. Oxford University Press, New York.

Cameron, K. \& Quinn, R., 2011, Diagnosing and Changing Organizational Culture: Based on the Competing Values Framework. Jossey-Bass, San Francisco.

Conrad, C. \& Poole, M.S., 2012, Strategic Organizational Communication: In the Global Economy. Wiley-Blackwell, Chichester. 
Gesteland, R.R., 2005, Cross-culture Business Behaviour. Copenhagen Business School, Copenhagen.

Haire, M., Ghiselli, E.E. \& Porter, L.W., 1966, Managerial thinking: An international study. Wiley, New York.

Hampden-Turner, Ch. \& Trompenaars, A., 1998, Siedem kultur kapitalizmu. Dom Wydawniczy ABC, Warszawa.

Hofstede, G., Hofstede, G.J. \& Minkov, M., 2011, Kultury i organizacje. Polskie Wydawnictwo Ekonomiczne, Warszawa.

Huntington, S., 2011, The Clash of Civilizations and the Remaking of World Order. Simon \& Schuster, New York.

Magstadt, T.M., 2012, Understanding politics. Cengage Learning, Belmont.

Mole, J., 2003, Mind your Manners: Managing Business Cultures in the New Global Europe. Nicholas Brealey, London.

Morgan, G., 1997, Obrazy organizacji. Wydawnictwo Naukowe PWN, Warszawa.

Ronen, S. \& Shenkar, O., 1985, 'Clustering Countries on Attitudinal Dimensions: A Review and Synthesis', The Academy of Management Review, vol. 10, no. 3, pp. 435-454.

Schein, E., 2010, Organizational Culture and Leadership. Jossey-Bass, San Francisco.

Wach, K., 2013, 'Kontekst europejski biznesu międzynarodowego w sektorze małych i średnich przedsiębiorstw' (chapter 7) In N. Daszkiewicz, K. Wach, Małe i średnie przedsiębiorstwa na rynkach międzynarodowych, Wydawnictwo Uniwersytetu Ekonomicznego w Krakowie, Kraków. 


\title{
Author
}

\section{Artur K. Modliński}

PhD student at the Department of International Marketing and Retailing at the University in Lodz. Master of art in international marketing and in political science. A personal image specialist with international experience, fluent in German, Russian, English, French, Italian and Swedish. Author of over twenty articles published in Poland and abroad. His research interest covers such areas as brand, intercultural and international marketing, communication strategy and consumer behaviors of various cultures and ethnic groups.

\author{
Correspondence to: \\ Mgr Artur Modliński (PhD Student) \\ University of Lodz \\ Faculty of International and Political Studies \\ Department of International Marketing and Retailing \\ ul. Targowa 3/3, 95-100 Zgierz, Poland \\ modlinski@uni.lodz.pl
}

